\title{
Corporate Governance: A Discussion on Minority Shareholder Protection in China
}

\author{
Judith Oliver ${ }^{1}$, Wen $\mathrm{Qu}^{2} \&$ Victoria Wise ${ }^{2}$ \\ ${ }^{1}$ Faculty of Business and Enterprises, Swinburne University, Melbourne, Australia \\ ${ }^{2}$ Deakin Graduate School of Business, Deakin University, Melbourne, Australia \\ Correspondence: Judith Oliver, Faculty of Business and Enterprises, Swinburne University, Melbourne, Australia. \\ Tel: 61-3-9214-8985. E-mail: juditholiver@swin.edu.au
}

Received: October 28, 2013

Accepted: December 19, 2013

Online Published: February 23, 2014

doi:10.5539/ijef.v6n3p111

URL: http://dx.doi.org/10.5539/ijef.v6n3p111

\begin{abstract}
This research paper discusses the agency problems derived from the ownership structure in Chinese listed firms and their implications to minority interest group protection in China. It analyses the regulatory framework for minority interest protection and role played by various regulatory agencies in the protecting the economic interest of minority interest in the Chinese listed firms. The paper concludes that in the emerging economy with its weak legal system to protect minority interests, judicial enforcement can be substituted by strong regulations.
\end{abstract}

Keywords: minority interest, ownership structure, Chinese stock market, corporate governance

\section{Introduction}

The aim of this study is to discuss the protection mechanisms and their effects on minority interest in the Chinese stock market. Due to the high proportion of state ownership in Chinese listed firms and its implication for information asymmetry, minority investor protection is a particularly important measure necessary to maintain the sustainable development of the Chinese stock market. The China Securities Regulatory Commission (CSRC, 2000), the capital market regulator in China, reports the Chinese stock market is primarily made up of individual investors who are segmented, segregated, and with relatively low shareholding ratios. These and other factors, such as geographic and time zone differences, individual shareholders have been restricted in their ability to participate in the management and significant decision-making of listed firms (CSRC, 2000). This has been further weakened by the lack of cumulative voting procedures which has given power to the firm's largest shareholder (typically the state).

Investor protection is a relatively new concept in Chinese society, and there are two ideological issues affecting the implementation of such protection in the Chinese stock market (CSRC, 2007). First, prior to the economic reform in late 1970s, China's centrally-planned economy was based on material production, and second, the income distribution principle is derived from the material production concept. As such there is doubt as to whether securities investment can create value in the way that material production does. Therefore, the CSRC recommends that it is necessary to promote an awareness and understanding of the need for investor protection.

If the legal system in China cannot provide the needed minority investor protection, then who should take on this role? It has been suggested that in such environments regulators can be an effective substitute for weak judicial systems (Glaeser et al., 2001) In China, the investor protection role can be jointly undertaken by the Ministry of Finance (MOF), the CSRC and stock exchanges (Chen et al., 2005; Berkman, 2008).

The remainder of the paper is structured as follows. Section 2 discusses the emerging of minority interest in China. Sections 3 and 4 look at concentration of share ownership and the agency problems caused by dominant state owned shareholders. Sections 5 and 6 focus on the development of corporate governance and establishment of corporate disclosure regulatory framework in China. Sections 7 and 8 discuss CSRC's enforcement and the role played by the stock exchanges in minority interest protection. Section 9 particularly documents market reaction to regulatory agencies' reactions. Conclusion remarks are presented in Section 10.

\section{Minority Interest in China}

With a population exceeding one billion, China's saving rate has been as high as an average $40 \%$ of national 
GDP. Since the mid 1990s, the high savings rate has been correlated to factors including traditional Chinese culture and family concepts. Many people prefer to have a bank deposit to fund their future retirement pension, education fees for children and the expenses of medical services and housing (China News, 2006). However, as part of the fiscal policy of the Chinese government, interest rates in China have remained low. Some investors have started to seek higher rates outside of traditional savings accounts and share investments have become increasingly more popular to maximize the return on their investment (People's Daily, 2005). After more than a decade of development, the number of individual investor accounts in the Chinese stock market has increased from 8.35 million in 1992 to nearly 226 million by the end of 2012 .

The trading behavior of Chinese domestic investors also increases the need for minority shareholder protection. Chinese domestic investors tend to seek profits short-term rather than looking for dividend income and capital growth. This is evidenced in 1995 when shares were being held for only 1-2 months, and increasing to only 5-8 months in 2002. Both are short holding periods when compared to the average 18 months in the United States (Deng \& Wang, 2006). The desire for quick profits suggests that small individual shareholders have no interest to monitor the management of the listed firms.

The revival of individualism in Chinese society has led to a growing sense of rights consciousness. As a consequence Chinese domestic investors are now more aware that they are able to use the legal mechanisms to protect their interests. Social changes since the late 1970's in Chinese society can explain this. For stability to be maintained, administrative and criminal law dominated civil action, and also the legalist school (and other philosophical schools) was dominated by the Confucius school. To maintain social stability, civil action was subservient to administrative and criminal law. In traditional Chinese society, administrative and judicial courts were combined with the head of the administrative court combined the roles of the executive, judge and legislator. The government discouraged private lawsuits, which were also not favored by the public. People bring action to the administrative courts were viewed as not following socially-accepted norms and had a nerve challenging the authority above them (Shao, 2003). Improved living standards and a more open society have contributed to change in some social norms and values. In 2001, nearly 900 compensation cases were lodged in the lower courts relating to fraudulent information provided in financial statements, insider trading and market manipulation (People's Daily, 2001). Investors who suffered financial losses due to the fraudulent information disclosed by listed firms filed complaints in the court. In November 2002 after a four year court battle, investors obtained compensation of RMB 224,000 (equivalent to US\$28,012) from a listed Chinese firm. The outcome of this case is the first civil compensation lawsuit against misleading financial information. The case reflects the attitude of government authorities and regulatory agencies towards strengthening legal enforcement of various regulations in respect of listed firms (Shao, 2003).

\section{Concentration of Share Ownership}

To understand the ownership structure of Chinese firms it is important to understand how the share structure has changed since the commencement of the stock exchange in the early 1990s. Prior to April 2005 shares were initially classified as either A-shares (only available to Chinese investors), B-shares (only available to foreign investors), H-shares (listed on Hong Kong Stock Exchange) and N-shares (listed on the New York Stock Exchange). The A-shares are further broken into state shares, legal-person shares, and tradable A-shares. The ownership of the state shares is with the central government and local government but the ultimate owner is the State Council of China. As state shares were not tradable on stock exchanges, the approval of the CSRC was required to transfer between domestic institutions. Domestic institutions such as stock firms, mixed enterprises (state and private), SOEs (having at least one non-state owner) held the legal-person shares. Until April 2005, legal-person owned shares were only allowed to be transferred between institutions. The justification for the trading restriction was for "control" of the company to remain with the state-owned or controlled shareholders. The only shares that were relatively freely traded among domestic investors were tradable A-shares owned by Chinese individual investors. The represented only one-third of total shares issued.

As can be seen above there were many different type of share categories in the Chinese stock market. In order to reduce this complexity, the government started a program in April 2005 to make all shares legally tradable and this was achieved by $94 \%$ of firms by mid-2006 (Jiang et al., 2008). As the result, the average proportion of state-owned shares has decreased from 51.3\% 2000 to 38.90\% in 2006 (CSRC, 2009).

\section{Agency Problems Caused by Dominant State-Owned Shareholders}

The concentration of ownership among listed firms in the Chinese stock market has created an agency problem. However, Xu and Wang (1999) suggest that the agency problem in the Chinese context is not in the diverged interests between management of firms and their shareholders, but in the form of conflicting interests between 
majority shareholders (state-owned shareholding) and minority shareholders (public shareholding). The following illustration of two interrelated issues is helpful in understanding how majority shareholders can exploit minority shareholders in listed firms.

The first issue is the close relationship between listed firms and their parent entities. The closeness is the direct result of the "privatization procedure" of SOEs in China. The Chinese government's original purpose of transforming SOEs into listed firms was to raise funds for SOEs and improve their performance, hoping that their operation could be more efficient and responsive to market competition. However, while the government has tried to give corporatized SOEs more autonomy, it is also concerned about the loss of controlling ownership rights. Many of the listed firms have been derived from the SOEs, in that the profitable elements of the enterprises became the new listed firm with the shares being sold to the public on the stock exchange (Firth et al., 2006), However, the SOE will often still retain the controlling interest in the listed firm and becomes the parent entity. Since the establishment of the Chinese stock market, state ownership has been the largest shareholder stake in many listed firms.

As majority shareholders of listed firms, state shareholders such as the state asset management bureau and local finance bureau are the organizations with authority to invest on behalf of the Chinese government. The equity stake of state shareholders in listed firms is normally converted from the properties previously allocated to SOEs prior to the SOEs being transformed into listed firms. Although the Chinese government declared in the mid-1990s that the ultimate owner of state shares is the State Council of China, there is no true owner representing these properties in a practical sense, as the State Council of China represents all of the citizens of the People's Republic of China (PRC). Firth et al. (2006) found that the majority of the ownership of the listed SOEs belongs to the state, as people in the state are supposed to be the masters of the country and owners of public properties in a socialist society. However, the public in general in China do not have direct control over public properties nor do they participate in the management of enterprises. Therefore, there is no true owner of state shares. Thus, this "lack of proper owner" of the state's stake is commonly regarded as the most important reason that has led to corruption and poor corporate governance among listed firms (Xu \& Wang, 1999; Shi \& Weisert, 2002).

Although the state investors have the major shareholding, they are not entitled to the dividends which have to be paid to the MOF or local government (Deng \& Wang, 2006). Another restriction is the direct involvement in the management of the listed firm. As a result, state investors must appoint representatives to work in the senior management positions. The selection and evaluation of senior management are often determined by the Chinese Communist Party (CCP) organizations; they must be members of the CCP and do not necessarily have the skills to manage a commercial business. The consequence of such a political process is that representatives of state investors do not play a significant role in terms of performance improvement and profit maximization. Research findings of Xu and Wang (1999), Hovey et al. (2003) and Leung (2007) show a negative relationship between state ownership and firms' performance.

The domination of state-owned shares is a common characteristic of Chinese listed firms. Such domination enables the majority shareholders to take advantage of this position to the detriment of minority shareholders' interests (DeFond et al., 1999). A typical example is the dominant shareholders' control of the funds of listed firms. Dominant shareholders divert capital resources to purposes other than business operations, in contrast to listed firms which promise not to in their communications with public investors in their IPO prospectuses. Statistics compiled by the CSRC show that, by 2004, the dominant shareholders of 350 listed firms had improper control of funds and about US\$7 billion of funds had been used for non-operating purposes. Among the listed firms which retreated from the stock exchange over the years, the most important reason for their failure was the dominant shareholders' control and the inefficient use of capital funds in listed firms (Tong, 2004).

The second issue derives from the first issue, being the "insider control problem". State ownership means there is a lack of effective external monitoring of the management of listed firms. The controlling power of listed SOEs is concentrated in the hands of the directors and senior management who share no material interests or risks in the company but exercise dominant power, free from the checks of market discipline. Rubber-stamped shareholders' meetings and dual roles undertaken by managing directors constitute the problem of insider control, enabling the controlling insiders to serve their own interests to the potential detriment of minority shareholders and even the whole firm. Deng and Wang (2006) list five typical insider controlling behaviors: (1) pursuing private benefits, such as embezzling firms' resources for perquisite consumption; (2) conducting market manipulation through misleading public investors or being engaged in insider trading; (3) seeking and retaining relationship advantages for themselves by using company resources, for example, state-owned firms may appoint persons who are helpful for them to keep good connections with government officials; (4) appropriating 
company funds to develop their own political background; and (5) dealing with creative accounting and releasing fraudulent financial information and over-investing or excessively consuming assets.

Due to the above issues the Chinese regulatory agencies have had the objective of protecting the interests of minority investors. The China Securities Regulatory Commission (CSRC) is of the view that a good corporate governance structure is essential to achieve minority investor protection in the Chinese stock market (CSRC, 2012).

\section{Corporate Governance in China}

Corporate governance in China was not seen as relevant until the mid-1990s. The enactment of the PRC Company Law in 1994 is regarded as a big step forward in improving corporate governance in China; however, when compared to other capitalist countries the legal system is still in its infancy (Berkman, 2008). China's first civil compensation suit regarding a securities case reflects on one hand, the activism of the investment community in China. On the other hand, as Chen et al. (2005) suggest, to have only one successful civil lawsuit in the first decade of the Chinese stock market is a glaring example of the to the lack of legal compensation in securities cases. In line with the Security Law, before a civil case can be made against a listed firm an investigation is required by the CSRC. This is further complicated as the Chinese legal system does not allow class action lawsuits which means that action brought about by individual investors has a low probability of succeeding and is also very costly (Chen et al., 2005).

In January 2001, the CSRC issued its Code of Corporate Governance for Listed Firms in China, based on the OECD Principles of Corporate Governance, 1999. The importance of corporate governance in China was strengthened by this Code (Tomasic \& Andrews, 2007). The CSRC's 2001 Code addresses several aspects of corporate governance, including shareholders and shareholders' meetings; listed firms and their controlling shareholders; directors and boards of directors; the supervisors and the supervisory board; performance assessment and incentives; and disciplinary systems and stakeholders. In China the PRC Company Law required that at a minimum the corporate structure of a limited liability company should consist of two levels of control: the Board of Directors and the Supervisory Board.

\subsection{Board of Directors}

The Board of Directors is responsible for shareholders. It must convene a general meeting and report; ; fulfill the resolutions that come out of the general meeting; develop the operating and investment plans; prepare the annual financial budget and financial statements; determine the distribution of profits; assess any need to change the registered capital of the company; determine the combination, separation, change or liquidation of the company; determine the design of the company's internal management organization and its establishment; and, to appoint or dismiss the management team and supervise their remuneration.

The Supervisory Board is responsible for the supervision of directors and senior officers. The structure of the Supervisory Board should consist of not less than three supervisors and be comprised of representatives of shareholders and a reasonable proportion of representatives of employees (Articles 52 \& 53, PRC Company Law). Directors, general managers and financial controllers should not hold a position concurrently as a supervisor. The duties of the supervisory board include supervising the directors and managers for any violation of laws, regulations or the articles of association of the company during their performance of company duties. They also have the right to examine the company's financial affairs, instruct a director or manager to rectify his/her actions if their actions are harmful to the interests of the company, and propose the holding of special shareholders' meetings.

The dominance of state ownership enables the original state-owned enterprises to exert control over managerial appointments and incentives. A survey conducted in 2000 by the CSRC reveals that the majority of board of directors was appointed via the state ownership. Meanwhile the independence of the board has been seriously weakened as the board is controlled by an insider as a result role the duality where the board member also acts as the chairman. The supervisory board is also incapable of identifying and addressing managerial corruption due to its lack of real authority and power. It can be concluded that a dominating state-owned share monopoly under internal control, is a major impediment in blocking the way for Chinese listed firms to improve their corporate governance practices.

There are two important regulations stipulated by the CSRC that listed firms must follow. First, the 2001 Guidelines for Establishing Independent Directors System for Listed Firms which is aimed at addressing the insider-controlled board structure by requiring that the board is to have at least one-third independent directors. Second, the 2002 Code of Corporate Governance for Listed Firms in China addresses both shareholder and 
stakeholder rights, director responsibility, management responsibilities and the need for information disclosure.

The appointment of independent directors is viewed as strong element of corporate governance to address the issue of "insider" control (Tomasic \& Andrews, 2007). A survey of listed firms in Shanghai, conducted by Tam (1995) in 1992, reveals the following board composition: independent directors, 30.6\%; representatives of legal-person ownership, 10.6\%; government department, $10.6 \%$; and representatives of foreign investors, $5.7 \%$. Compared to an average of $75 \%$ independent directors on the board of publicly-listed firms in the US, the proportion of independent directors in firms listed on the Shanghai Stock Exchange is relatively low. Several high profile corporate scandals in 2000 and 2001 highlighted the poor corporate governance practices among listed firms in the Chinese stock market. The existence of both a Board of Directors and a supervisory board did not prevent the disclosure of false information.

The Code of Corporate Governance for Listed Chinese Firms issued by the CSRC has noted the main role of independent directors to be the protection of investors' rights, in particular minority investors. Authority is also given to independent directors to submit proposals to call shareholders' meetings, recruit or dismiss accounting firms, invite in independent auditors and offer independent financial reports. Independent directors also have a major oversight role as they must have majority membership in the major board committees those being the audit, compensation and nomination committee. In additional any major related-party transactions require their approval. Tomasic and Andrews (2007) consider the role of played by independent directors has been a positive contribution to the credibility of corporate disclosure and protection of minority investor' interests in China.

The CSRC recognizes that rules and regulations will not necessarily bring about investor protection in the Chinese stock market unless proper training of the main participants of the Chinese stock exchange and strong enforcement are implemented. To promote corporate governance practice among listed firms, the CSRC conducts workshops and training courses. The requirement for independent directors has created a huge demand for qualified directors. By offering training courses on the roles and responsibilities of directors, the CSRC is able to develop a pool of candidates from which the listed firms can choose independent directors (Zhang, 2001). Monthly training classes for independent director candidates were run in big cities including Beijing, Shanghai and Shenzhen. There are several studies investigating corporate governance practices among listed firms in the early stages of the Chinese stock market. Xu and Wang (1999) suggest that due to the dominating state-owned share monopoly, and insider control, the three tiers of control - the shareholders' meeting, the Board of Directors, and the Supervisory Board, did not function effectively or efficiently. Shareholders in China appear to have more managerial power than their counterparts in many Anglo-American countries as they are able to call for meetings, elect and replace directors and supervisors, and approve the reports provided. In addition, they also have the right to examine the corporate final accounts, decide whether to issue additional shares and make decisions regarding corporate mergers, dissolution and liquidation. However, research findings show that shareholders' meetings are often merely "rubber stamped" (Xu \& Wang, 1999).

\subsection{Supervisory Board}

In addition to the board of directors, another corporate governance monitoring mechanism in China is the Supervisory Board. Chapter 4 of the Code of Corporate Governance for Listed Chinese Firms is devoted to the illustration of the composition and duties of the supervisory board. Under the Code of Corporate Governance for Listed Chinese Firms supervisors are required to have the requisite knowledge or experience in relation to law and accounting. This knowledge and experience is important to ensure that the supervisors are capable to independently and efficiently take the role of supervising senior executives in the firm, as well as the financial management. Despite the above requirements for supervisors, Xing (2003) argues that in practice supervisors tend to focus more on the administrative matters rather than the supervisory role. This is a result of several factors including: the failure of the Company Law to specify how the supervisory board should function; ; is the composition of the supervisory board being composed of shareholder representatives (with likely connections to the controlling shareholder) and employee representatives who will be faced with the challenge of acting against their supervisors; and finally the lack of an evaluation and incentive system to assess the supervisory board In October 2005, a revised Company Law marked a major step-forward in strengthening corporate governance in China. The Company Law significantly increased the supervisory board's power in monitoring directors and senior management. The supervisory board now can question and propose board of directors' resolution items as well as investigate when it discovers irregularities in how the firm is being managed. Further, it can hire an external accounting firm to help with an investigation if it is necessary (Article 55 and 119, The Company Law).

\section{Establishment of a Corporate Disclosure Regulatory Framework}

To improve the efficiency of the stock mark and protect shareholders the CSRC developed a corporate disclosure 
regulatory framework (CSRC, 1996). The regulatory framework of corporate information disclosure in China is comprised of four tiers. The corporate disclosure régime is built of regulations stipulated by the National People's Congress, the State Council, the CSRC and the stock exchanges in Shanghai and Shenzhen.

At the top of this framework are the basic laws released by the National People's Congress, the PRC Company Law and the PRC Securities Law promulgated in 1993 and 1999, respectively. The Company Law imposes legal responsibilities on public issuing firms to disclose their financial reports to public shareholders, to not provide fraudulent financial information and fines for non-disclosure fines. The Security Law aims to regulate share issuing and the trading of shares. The law requires listed firms' to make continuous disclosure, forbids fraud, insider trading and market manipulation in issuing and trading securities. Article 69 of the Security Law provides protection to investors if losses are incurred due to false, misleading or major omissions. If this occurs the issuer or the firm shall be liable for the losses, as well as responsible director(s), supervisor(s) and/or the manager of the issuer or the firm who shall be jointly and severally liable for such losses.

The second layer of the framework is the administrative regulations released by the State Council. In April 1993, after three years of stock exchange operation in China, the Temporary Regulation of Share Public Issuing and Trading became the first regulation to standardize the information disclosure of listed firms. However, for listed firms, it is still a principle rather than a practical guide. This regulation determines the direction and emphasis for the stock market regulator-the CSRC. It is the CSRC's responsibility to produce detailed guidance to assist listed firms to implement the administrative regulations.

The third layer of the framework is Detailed Rules for Implementation of Information Disclosure of Publicly Listed Firms released by the CSRC in June 1993. This was the first regulation in a series of disclosure rules to the transparency of information disclosure made by listed firms.

Of these standards, Number 2 the Contents and Formats of Listed Firms' Annual Reports is the first regulation for the content and format of annual reports in the Chinese stock market. Since its promulgation there have been a number of revisions which have required firms to disclosure more information to the market in relation to ownership structure and the profile of directors and management in regards to their work experience and education. The CSRC has also implemented steps to improve the usefulness of information disclosed in the annual report (Hu, 2002). To protect the interests of public investors, the CSRC requires firms to disclose information regarding earnings distribution, dividend policy, and the reasons for retaining earnings rather than paying a dividend. In the case of firms with parent entities, disclosure is required from the listed firm as to the degree of separation between management personnel and the financial recording system. Further, this regulation deals with the independence of the accounting and auditing firms with the requirement for the annual report to include an auditor's report.

Due to the geographic spread of individual investor the CSRC requires listed firms to make information available through a number of different avenues such as the firm's premises, the stock exchange, the relevant licensed brokers and their branches, and the internet (CSRC, 2000).

The fourth of the framework layer is the listing rules and specific guidance released by the two stock exchanges. These rules and guidance are subject to the approval of the CSRC. In 1998, the Shanghai and Shenzhen stock exchanges have released Rules Governing the Listing of Securities which further define the stock exchange's forefront surveillance responsibility of information disclosure.

\section{CSRC Enforcement of Stock Market}

Each year the CSRC releases new policies to promote and protect investor interest (People's Daily, 2005). More than 300 regulatory requirements (either regulation, rule, standard or guideline) has been issued by the MOF and CSRC since 1992. The CSRC views it role as that of an enforcer to supervise the security market; to exercise authority over regional and provincial supervisory institutions; to investigate and penalize activities that violate the securities laws and regulations. The enforcement role taken by the CSRC acknowledges the strong supervision of listed firms that is expected by investors. Severe penalties are given to firms by the CSRC if they do not provide timely, adequate and transparent information to the capital market (People's Daily, 2005). This strengthening of the role of the CSRC is in contrast to the early and mid-1990swhen its actions were considered ineffective due to weak actions and lax punishment (Chen et al., 2005). However, sine 1998, the CSRC now has overall regulatory power over the securities industry.

The CSRC initiates investigations based on a number of leads. According to Chen et al. (2005), leads include complaints from investors, information from insiders or former employees of firms, newspaper articles, analyses of annual reports and other corporate disclosures, referrals from the stock exchanges, legal disputes and police 
investigations. In addition to formal investigations, the CSRC also conducts on-going surveillance of listed firms and has a practice of regular reviews and random investigations. The process is similar to that of the Securities and Exchange Commission (SEC) in the US. The results of the CSRC's investigations are made public if wrong-doing is found. If an infraction is deemed to be very minor, the CSRC will give an internal warning to the firm and there will be no public disclosure of either the investigation or its outcome. Public admonishments stipulated in the Security Law take four main forms. They are public criticism, public condemnation, official warning and monetary fines. For individuals, the sanctions can include criminal prosecution and carry severe penalties. Such as, when in 1999 the chairman and general manager of another listed Chinese firm, Dongfang Boile were sentenced to death for fabricating financial statements. The CSRC regards investigation and enforcement as the most direct and effective approach for investor protection. In 2011, upholding a 'zero tolerance' policy in cracking down on insider trading and other securities and future trading, when the CSRC initiated investigation of 209 cases which include alleged violations in insider trading, market manipulation and false financial information disclosure. The investigations led to 57 decisions on administrative sanctions and 11 decisions on ban of market entry; referred 25 suspected criminal violations to public security authorities and enforced fines and confiscations of RMB 348 million. In 2011, the CSRC also established the Investor Protection Bureau, an organization responsible for the general planning, organization, supervision of activities, to further strengthen investor protection (CSRC, 2011). Continuing its efforts, in 2012, the CSRC investigated a further 34 cases of information disclosure violations, 33 cases of insider trading and 10 cases of market manipulation. As a result, it imposed 56 administrative sanctions and 8 bans of market entry and referred one case to the judicial authorities. 17 listed Chinese firms, 2 auditing firms and 168 individuals were involved in these administrative sanctions, and fines and confiscations reached RMB 437 million (CSRC, 2012).

The CSRC acknowledge the importance of high quality financial information in ensuring the efficiency of the Chinese stock market. To this end, in enforcing the Chinese accounting standards the MOF, jointly with the CSRC, supervise financial accounting information disclosures made by listed firms on the Chinese stock market. In 2012, the CSRC reviewed the annual reports of listed Chinese firms and released a Report on the Supervision of Implementation of Accounting Standards (CSRC, 2012). It has the power to sanction listed firms and their auditors if non-compliance with accounting standards and audit criteria or false financial information is found. Penalties for CPA firms that do not apply appropriate standards can include cancellation of licenses both temporarily and permanently.

Elimination of corruption is at the center of CSRC's work. It has given assurances to the public that it will ensure that through its work the capital markets will be efficient. Plans were issued in 2005 by the State Council mapping plans for stock market reform. The former chairman of the CSRC, Shang Fulin, stated that the priority for the reforms would be strong protection of the interests of public investors and the development of a culture of accountability (CSRC, 2000). The CSRC has also increased its interaction with the media and public investors through mechanism that include offering more detailed introductions of the new policies to investors, and conducting more interviews with the media.

Since 2003, to further enhance transparency the CSRC's via its website names the members of the listing approval committee who review stock and bond issue applications. Further, corruption is being addressed with the CSRC creating legal access for normal communications between listing committee members and the listing applicants. This will allow the opportunity for listing applicants to both introduce their enterprises and respond to problems raised during reviews (CSRC, 2005).

\section{The Stock Exchanges' Role in Investor Protection}

Under the close supervision of the CSRC, Shanghai and Shenzhen stock exchanges established their own listing rules in 1998 and strengthened their roles in supervising information disclosure. While endeavoring to provide facilities for securities trading and associated monitoring, the two stock exchanges also participated in championing the improvement of corporate governance especially in respect of protecting investors' interests and the transparency of information disclosure. In 2003, the Shenzhen Stock Exchange issued the Guidelines on Protection of Investor Rights and Interests for Small and Medium Enterprises Board. Article 12 of this guideline stresses that listed firms should truthfully, accurately, completely and be timely in disclosing the information that may significantly impact the price of stocks and derivatives or the decision-making of investors, and such information must not contain falsehoods, misleading statements or material omissions. Further, the disclosure obligation is, based on the principle of good faith, so there is an expectation of voluntary disclosure of other information that is not required by laws, regulations or the rules of the stock exchanges. Access to the information should be equitable and selective disclosure should not occur. Article 13 emphasizes that "when making voluntary disclosure of forward-looking financial information, listed firms shall follow the internal audit 
procedures, issue risk warnings to investors stating the assumption basis for such forward-looking information and any uncertainty involved and, in accordance with actual conditions and in a timely manner, modify the information previously disclosed".

In addition to releasing and implementing rules to regulate information disclosure by listed firms and safeguard the interests of public shareholders, the two stock exchanges also take some action to maintain the sustained development of the stock market. For example, they monitor the dominant shareholders' illegal use of funds of listed firms; in conjunction with the assistance of local governments they enforce the return of funds to listed firms by state shareholders to ensure the capital resources raised from the stock exchange are used for legitimate purposes. The Shanghai Stock Exchange has also released reports to expose bad behavior of some security investment firms in the stock market. Taking a similar attitude as the CSRC in respect of investor protection, the two stock exchanges also undertake strong enforcement to promote transparent disclosure in the stock market.

\section{Market Reaction to Regulatory Agencies' Actions}

Market reactions to the CSRC's actions are investigated by Chen et al. (2005) and Berkman (2008). Chen et al. (2005) provide empirical evidence on how the valuation of listed firms was impacted by the regulatory agencies' enforcement actions. In their study, the authors identify 169 enforcement actions carried out by the CSRC in the period 1999-2003. Using event study research methodology, Chen et al. (2005) find firms suffered wealth losses of around $1-2 \%$ in the five days after the CSRC enforcement actions were implemented. Moreover, they find that firms have a greater rate of auditor change; a much higher incidence of qualified audit opinions; increased CEO turnover; and wider bid-ask spreads. The negative stock returns and the costly economic consequences for listed firms suggest that the regulatory agencies in the Chinese stock market have credibility and their actions have "teeth".

Berkman (2008) adopts an event study methodology to examine the stock market reactions to three CSRC regulations aimed at reducing expropriation from public investors by controlling shareholders. The regulations increased the rights of public investors at a firms' annual shareholders' meeting; prohibited the issuance of loan guarantees by a firm to its controlling shareholder; improved the transparency and regulation of asset transfers to related parties. Berkman (2008) finds that weak governance leads to significant positive abnormal returns and provides evidence that regulation can be effective in protecting public investors from expropriation in a country with weak judicial enforcement.

Both an independent directors system and an audit committee are advocated by the CSRC as good corporate governance mechanism. Independent directors can effectively monitor management's performance and represent public shareholders' interest. In the process of establishing an independent director system, the CSRC not only exerted its power by stipulating an important regulation, Guide Opinion on Establishing Independent Director System by Listed Firms, but also organized training of independent directors and set up an "independent director candidature pool" for listed firms. Audit committees are supposed to monitor firms' internal controls and review the internal audit system. Establishing an audit committee was also recommended by one of the CSRC's regulations stipulated the Code of Corporate Governance for Listed Firms in China.

\section{Summary}

The Chinese stock market was established in 1990 with the opening of Shanghai stock exchange. The unique ownership structure among listed firms has consequently caused an agency problem. Resolving the conflicting interest between majority shareholders and minority shareholders requires further transparency in terms of corporate disclosure. To this end, a regulatory environment has been gradually established by the Chinese government to facilitate a more attractive business environment. As government agencies, the MOF and the CSRC jointly oversee the administration of the Chinese stock market. Both of them promote transparency of disclosure and protection of the minority interests. Established in 1992, the initial function of the CSRC was to perform administrative roles such as approving the listing and reviewing the share transfers of state shares and legal shares among institutional investors. Overtime, the CSRC has moved to regulate listed firms' information disclosure and fraudulent behavior. The pro-active role taken by the CSRC has strengthened corporate governance through its enforcement of rules thus protecting the integrity of the Chinese stock market, and in supporting the rights of public investors (Tomasic \& Andrews, 2007). Research shows their actions are plausible as the market responds to them positively.

\section{References}

Berkman, H. (2008). Political connections and minority-shareholder protection: Evidence from securities-market regulation in China. AFA 2009 San Francisco Meeting Paper. Retrieved from 
http://ssrn.com

Chen, G., Firth, M., Gao, D. N., \& Rui, O. L. (2005). Is China's securities regulatory agency a toothless tiger? Evidence from enforcement actions. Journal of Accounting and Public Policy, 24, 451-488. http://dx.doi.org/10.1016/j.jaccpubpol.2005.10.002

China News. (2006). Making sense of China? Why saving rate is so high. Retrieved from http://www.chinadaily.com.cn

CSRC. (1996). Announcement of Some Rules on the Issuance of Shares.

CSRC. (2000). Information disclosure and corporate governance in China.

CSRC. (2007). Speech by CSRC Chairman Zhou Xiaochuan at the International Symposium on investor protection. Retrieved from http://www.crsc.gov.cn

CSRC. (2009). CSRC Annual Report.

CSRC. (2011). CSRC Annual Report.

CSRC. (2012). CSRC Annual Report.

DeFond, M. L., Wong, T. J., \& Li, S. (1999). The impact of improved auditor independence on audit market concentration in China. Journal of Accounting and Economics, 28(3), $269-305$. http://dx.doi.org/10.1016/S0165-4101(00)00005-7

Deng, X., \& Wang, Z. (2006). Ownership structure and financial distress: Evidence from public-listed firms in China. International Journal of Management, 23(1), 486-502.

Firth, M., Fung, P. M. Y., \& Rui, O. M. (2006). Corporate performance and CEO compensation in China. Journal of Corporate Finance, 12, 693-714. http://dx.doi.org/10.1016/j.jcorpfin.2005.03.002

Glaeser, E., Johnson, S., \& Shleifer, A. (2001). Coase versus the coasians. Quarterly Journal of Economics, 116, 853-899. http://dx.doi.org/10.1162/00335530152466250

Hovey, M., Li, H., \& Naughton, T. (2003). The relationship between valuation and ownership of listed firms in China. Corporate Governance, 11(2), 112-122. http://dx.doi.org/10.1111/1467-8683.00012

Leung, Q. W. Y., Morris, R. D., \& Gray, S. J. (2005). Corporate Transparency in Annual Reports of Chinese Listed Firms. Conference paper, AFAANE Conference, Accounting and Finance Association of Australia and New Zealand, 3-5 July, Melbourne, Victoria.

People's Daily. (2001). Stock Market Being Sensibly Regulated.

People's Daily. (2005). China's Development Brings Opportunities to the World.

Shao, Z. W. (2003). Civil law on Fraud Evolves. China Daily, 10(January).

Shi, S., \& Weisert, D. (2002). Corporate Governance with Chinese Characteristics. The Chinese Business Review, $29(5), 40-44$.

Tomasic, R., \& Andrews, N. (2007). Minority shareholder protection in China's top 100 listed firms. Retrieved from: http://ssrn.com

Tong, D. C. (2004). Comparative corporate governance: the case of Chinese publicly listed firms. CSRC. Retrieved from http://www.rieti.go.jp

Xiao, Z. Z. (1999). Corporate disclosures made by Chinese listed firms. The International Journal of Accounting, 34(3), 349-373. http://dx.doi.org/10.1016/S0020-7063(99)00018-7

Xinhua Press. (2005). Non-performing loans of Chinese commercial banks. Retrieved from http://www.xinhuanet.com

$\mathrm{Xu}, \mathrm{X}$., \& Wang, Y. (1999). Ownership structure and corporate governance in Chinese stock firms. China Economic Review, 10, 75-98. http://dx.doi.org/10.1016/S1043-951X(99)00006-1

\section{Copyrights}

Copyright for this article is retained by the author(s), with first publication rights granted to the journal.

This is an open-access article distributed under the terms and conditions of the Creative Commons Attribution license (http://creativecommons.org/licenses/by/3.0/). 